\title{
Mediating effect of SATCOM on the relationship between consumer complaint behaviour and relationship quality
}

\author{
Mohd. Khirzanbadzli A. Rahman 1,2,*, Norlida Jaafar ${ }^{2}$, Laily Paim ${ }^{3}$, Syuhaily Osman ${ }^{3}$, Sharifah Azizah Haron 3,4 \\ 1Institute of Business Excellence, Universiti Teknologi MARA, 40450 Shah Alam, Selangor, Malaysia \\ ${ }^{2}$ Faculty of Business and Management, Universiti Teknologi MARA, 40450 Shah Alam, Selangor, Malaysia \\ ${ }^{3}$ Faculty of Human Ecology, Universiti Putra Malaysia, 43400 Serdang, Selangor, Malaysia \\ ${ }^{4}$ Malaysian Research Institute on Ageing (My Ageing), Universiti Putra Malaysia, 43400 Serdang, Selangor, Malaysia
}

\section{A R T I C L E IN F O}

\section{Article history:}

Received 5 November 2016

Received in revised form

6 January 2017

Accepted 11 January 2017

\section{Keywords:}

Consumer complaint behaviour

Satisfaction with complaint handling

Relationship quality

\begin{abstract}
A B S T R A C T
In the study, consumer complaint behaviour (CCB) was represented by Public Complaint Soft Action (PCSA) and Public Complaint Extreme Action (PCEA) as the independent variable, SATCOM the mediating variable and relationship quality the dependent variable. A total of 285 mobile phone users consisting of complainers from three selected states in Malaysia were chosen as the respondents. Using structural equation modelling (SEM) the structural model shows excellent fit with $\mathrm{x}^{2}=695.922, \mathrm{x}^{2} / \mathrm{df}=2.245, \mathrm{CFI}=$ $0.932, \mathrm{TLI}=0.923, \mathrm{PNFI}=0.781$ and RMSEA $=0.071$. Besides, the AVE, CR and Convergent Validity values confirmed the measurement model for further analysis. Employing bootstrapping technique to test the mediation effect, this study reveals mixed results. SATCOM is found significantly a full mediator on the relationship between PCSA and relationship quality ( $\beta=$ $0.246, p=0.000$, BC 95\% CI $[0.047,0.282])$, but not a mediator on the relationship between PCEA and relationship quality $(\beta=-0.096, p=0.169, B C$ $95 \%$ CI $[-0.174,0.031])$. This finding implies that the performance of the complaint resolution by the service provider will give impact to the consumer, as well to the service provider because customer dissatisfaction can be speedily recovered through excellent complaints handling.
\end{abstract}

(C) 2017 The Authors. Published by IASE. This is an open access article under the CC BY-NC-ND license (http://creativecommons.org/licenses/by-nc-nd/4.0/).

\section{Introduction}

Out of 44 million (NCCC, 2015) mobile phone services in Malaysia only 5,868 (MCMC, 2015) filed their complaints. The small percentage of complainers indicates that there are issues need to be identified and solved for the benefits of the consumers as well as the service providers. One of the important issues is satisfaction with the complaint handling (SATCOM).

Like other types of satisfaction, SATCOM gives a great impact to the consumers as well as to the organizations. According to Stauss (2002), "complaint satisfaction" is the satisfaction of a complainer with a company's response to his or her complaint. The results of the evaluation determine the satisfaction level of the complainers. SATCOM has also served the role of mediator that links

\footnotetext{
* Corresponding Author.

Email Address: khirzan@puncakalam.uitm.edu.my (M. K. A. Rahman)

https://doi.org/10.21833/ijaas.2017.03.013

2313-626X/@ 2017 The Authors. Published by IASE.

This is an open access article under the CC BY-NC-ND license

(http://creativecommons.org/licenses/by-nc-nd/4.0/)
}

perceptions of the justice dimensions to post complaint outcomes (Tax et al., 1998; Gelbrich and Roschk, 2011). Varela-Neira et al. (2010) said that although most researches have hypothesized SATCOM as mediator, the results are mixed. Thus, this study looks into the effect of SATCOM on the relationship between consumer complaint behaviour and relationship quality. The finding implies that the performance of the complaint resolution by the service provider will give impact to the consumer, as well to the service provider because customer dissatisfaction can be recovered quicker through high level of SATCOM.

\section{Literature review}

\subsection{Consumer complaint behaviour}

Throughout the decades the concept of consumer complaint behaviour (CCB) has gone through several developments. Initially, CCB has been classified as two-level of hierarchical actions resulted from dissatisfaction (Day and Landon, 1977). In the development, a number of authors divided CCB as two types of responses namely public 
and private action (Bearden and Oliver, 1985; Ndubisi and Ling, 2006). Public action has been described as seeking redress directly, seeking refund from the seller, complaining to the media, instigating legal action and taking direct complaint action to the firm or consumer agency (Heung and Lam, 2003). On the other hand, private action has been characterized as switching brands and firms, boycotting a firm's products, ceasing to patronize an establishment and negative word-of-mouth communications to friends and relatives (Kim et al., 2003; Tronvoll, 2011). Empirical evidence shows that the results of dissatisfaction are public action, private action and no action (Day and Landon, 1977; Crie, 2003; Ndubisi and Ling, 2006), voice, private and third party (Singh, 1988), switching, making a complaint to the seller and telling the experience to others (Richins, 1983) and retaliation, grudgeholding and avoidance (Hunt and Hunt, 1990). Rahman et al. (2015) suggested that consumer complaint behaviour consists of public complaint soft action (PCSA), public complaint extreme action (PCEA), private complaint soft action (PVSA) and private complaint extreme action (PVEA) complainers. The non-complainer only involves private complaint soft action (PVSA) and private complaint extreme action (PVEA). Thus, this paper aims to highlight the mediating effects of SATCOM on the relationship between CCB (PCSA and PCEA) and relationship quality. PVSA and PVEA are excluded due to the fact that these two actions do not directly involve with complaint handling process.

\subsection{Satisfaction with complaint handling}

Several synonyms for satisfaction with complaint handling are found in the literature such as "secondary satisfaction" (Etzel and Silverman, 1981; Oliver, 1997), “complaint response satisfaction" (Blodgett and Grandbois, 1992), "service recovery satisfaction" (De Ruyter et al., 2001), "satisfaction with complaint resolution" (Andreassen, 1999) "satisfaction with service recovery" (Maxham and Netemeyer, 2002), "overall complaint satisfaction" (Stauss, 2002), "satisfaction with the remedy" (Harris et al., 2006) or "recovery disconfirmation" (McCollough et al., 2000). Stauss (2002) said that complaint satisfaction is the satisfaction of a complainer with a company's response to his or her complaint. This study used satisfaction with complaint handling adopted from Varela-Neira et al. (2010) to indicate complaint satisfaction by comparing the actual performance and the expectation of the complaint handling procedures.

\subsection{Relationship quality}

Relationship quality is a construct that has a number of definitions. It has been defined as an overall assessment of the strength of a relationship (Smith, 1998; De Wulf et al., 2001), involving the seller/service provider's integrity and ability to reduce uncertainty (Roloff and Miller, 1987; Crosby et al., 1990), salesperson's integrity with the customer's confidence in the salesperson's future performance (Crosby et al., 1990) and the degree of appropriateness of a relationship to fulfil the needs of the customer associated with that relationship (Hennig-Thurau and Klee, 1997). Evidently, there is no consensus on the dimensions that make up relationship quality. However, satisfaction, trust and commitment have been emphasized as the important indicators of relationship quality (Crosby et al., 1990; Hennig-Thurau and Klee, 1997; De Wulf et al., 2001). On the other hand, in an industrial context, specific dimensions are added from buyer-seller relationships. In this study, relationship quality is the dependent variable which is adopted from Roberts et al., (2003). The dimensions consist of trust in partner's honesty, trust in partner's benevolence, commitment, satisfaction and affective conflict. The reason for adopting Robert's study is that, the dimensions are appropriate in assessing relationship quality in a services industry.

\subsection{Consumer complaint behaviour and relationship quality}

Study specifically on the relationship between consumer compliant behaviour and relationship quality is scant. However, previous studies have showed significant relationships between behaviour and relationship quality (Lagace et al., 1991). In another study, ethical behaviour and relational selling behaviour were found to have relationship with relationship quality (Boles et al., 2000; Lin and Ding, 2005). Similarly, complaining is regarded as communication in previous studies (Alicke et al., 1992; Shapiro and Nieman-Gonder, 2006). Ndubisi (2007) has included conflict handling, communication, trust and commitment as the antecedents of relationship quality and the results showed that all four antecedents are significantly associated with relationship quality. Several researchers have employed communication as the antecedent to relationship quality (Kim et al., 2006), communication barriers (Menon et al., 1996), initiating communication (Leuthesser, 1997), effective communication (Goodman and Dion, 2001; Sanzo et al., 2003) two-way communications (Bennett and Barkensjo, 2005) and communication quality (Athanasopoulou, 2006).

Empirically, there is a strong theoretical background that complaint behaviour has relationship with relationship quality.

\subsection{Consumer complaint behaviour and satisfaction with complaint handling}

Bearden and Oliver (1985) have conducted a study to identify the effect of public or private complaint action on the resolution satisfaction. Evidently, resolution satisfaction was positively related to public complaining and negatively related to private complaining. Resolution satisfaction can 
be construed as complaint satisfaction that also includes "satisfaction with complaint resolution" (Andreassen, 1999). Complaint handling can also be called as service recovery. Service recovery is a process where the organizations eliminate customers' dissatisfaction towards the service failure (Grönroos, 1988). Clearly, service recovery involves public complaints where the customers meet the service provider to lodge their dissatisfaction. In this study, the focus is on public complaint as in the actual process in order to ensure the performance of complaint resolution can be assessed.

\subsection{Satisfaction with complaint handling and relationship quality}

Study specifically on the relationship between complaint satisfaction and relationship quality is lacking. However, there are studies on satisfaction with complaint or complaint satisfaction which evidently show the relationship with overall satisfaction (Ambrose et al., 2007; Maxham and Netemeyer, 2002) trust (Kau and Loh, 2006; Weun et al., 2004) and commitment (Tax et al., 1998; Weun et al., 2004). Literary, satisfaction, trust and commitment are the dimensions in relationship quality. Hence, in this study the relationship between complaint satisfaction and overall satisfaction, trust or commitment is posited as the relationship between SATCOM and relationship quality.

\subsection{Satisfaction with complaint handling as a mediator}

Study on the role of complaint satisfaction or satisfaction with complaint handling (SATCOM) as the mediating variable is inadequate. Most studies related to SATCOM used SATCOM as either the independent or dependent variable (Tax et al., 1998; Stauss, 2002; Weun, et al., 2004; Homburg and Furst, 2005; Ambrose et al., 2007; Varela-Neira et al., 2010). However, Orsingher et al., (2010) have studied the role of SATCOM as a mediator in their study and the results are mixed. Empirically, the concept of satisfaction is an important construct to play as mediator in other area of studies such as in marketing (Caruana, 2002), human resource (Chiu and Francesco, 2003; Mount et al., 2006) organizational (Lok and Crawford, 2001) and communication (Carriere and Bourque, 2009). Hence, in this study it is hypothesized that satisfaction with complaint handling mediates the relationship between CCB and relationship quality.

\section{Methodology}

\subsection{Scale and measurement}

The questionnaire comprises of 4 sections to obtain data on the demographic profile, complaint behaviour, satisfaction with complaint handling and relationship quality. All items were adapted from previous studies (Liu and McClure, 2001; Roberts et al., 2003; Ndubisi and Ling, 2006; Varela-Neira et al., 2010; Rahman et al., 2015). Satisfaction with complaint handling (SATCOM) was assessed by 5 items adopted from Varela-Neira, et al. (2010) and finally relationship quality was assessed by 15 items adopted from Roberts et al. (2003). Items to measure CCB, SATCOM and relationship quality were rated on a 5-point Likert scale, which ranged from $1=$ strongly disagree to $5=$ strongly agree.

\subsection{Data collection procedures}

The population for the study was the subscribers of mobile phone services from all service providers Maxis Berhad (known as Maxis), DiGi Telecommunication Sdn. Bhd. (known as DiGi), Celcom Axiata Berhad (known as Celcom) and Umobile in the state of Selangor, Federal Territory of Kuala Lumpur and Putrajaya. Subscribers from these three states were chosen based on the fact that the total number of subscribers from these states represents $28.6 \% \quad(1,945,143)$ of the total subscribers in Malaysia. Besides, the respondents were deemed eligible to represent those from other states in terms of culture and values because the population in these locations comes from various states in Malaysia. This is to ensure the representativeness of samples. Using mall-intercept approach twelve shopping malls in Selangor, Kuala Lumpur and Putrajaya were selected as the centres for data collection activity.

\subsection{Confirmatory factor analysis, validity and reliability}

In this study unidimensionality assessment was performed prior to testing the reliability and validity of each construct (Anderson and Gerbing, 1988; Dunn et al., 1994; Hair et al., 2010). According to Hair et al. (2010), unidimensionality is as an assumption underlying the calculation of reliability and is demonstrated when the indicator of a construct has an acceptable fit on a single-factor (one-dimensional). Using AMOS version 21, CFA was employed to explore statistical relationships among the items of each factor as well as to verify the unidimensionality. The goodness-of-fit are used to verify the model fitness as well as to determine how well the model best representing the data reflects the underlying theory (Ho, 2006). The fit indices of Root Mean Squared Error Approximation (RMSEA), normed Chi-Square $\left(\chi^{2} / \mathrm{df}\right)$, Tucker-Lewis Index (TLI), Normed Fit Index (NFI), Parsimony Normed Fit Index (PNFI) and Comparative Fit Index (CFI) were considered in the study (Hair et al., 2010) to ensure the multivariate effect.

The construct validity and convergent validity were examined to test the robustness of the model. The reliability and validity of the underlying constructs were assessed using alpha value of Cronbach (1951), construct reliability (CR) and 
average variance extracted (AVE). Validity was assessed using construct, convergent and discriminant validity. In using confirmatory factor analysis, CR and AVE were calculated from model estimates using the formula given by Fornell and Larcker (1981). CR should be equal to or greater than 0.60 , and AVE should be equal to or greater than 0.50 (Bagozzi and Yi, 1988). Construct validity exists when the measure is a good representation of the variable that the researcher intends to measure, and it is a necessary pre requisite for theory testing. In this study, the results obtained from goodness-offit indices will confirm the construct validity (Hsieh and Hiang, 2004). As for convergent validity, all factor loadings for items measuring the same construct must be statistically significant (Anderson and Gerbing, 1988). The results of AVE provide an additional support for convergent validity. Discriminant validity was achieved by deleting the redundant items, a reason for the high correlation. Through the results of pattern structure, coefficients show that each factor in each measurement model was empirically distinguishable.

\section{Results and discussion}

\subsection{Demographic background of respondents}

This study involved 285 mobile phone services users identified as complainers from the state of Selangor, Federal Territory of Kuala Lumpur and Putrajaya in Malaysia. Demographic information from the sample showed that 141 of the respondents were males (49.5\%) and 144 were female (50.5\%). Most of the respondents were in the age range between 21 to 30 years old (49.6\%). In terms of marital status, married respondents were slightly higher $(53.0 \%)$ than the other categories. Although majority of the respondents were subscribing to one service provider, a substantial percentage of the respondents (35.4\%) subscribed to two mobile phone services.

\subsection{Overall CFA measurement model, validity and reliability}

The overall measurement model involved all constructs in the study-PCSA, PCEA, PVSA, PVEA, SATCOM and relationship quality. The goodness-offit indexes were examined to verify the fitness of the overall model. During the re-specification process three items, CCB14, RQ1 and RQ4 were deleted from the model. The results indicated that the overall measurement model was a good-fitting model although the value of GFI (0.838) was slightly below the threshold value $(>0.90)$. Other indices showed good values where the CFI $=0.936$, TLI $=0.927$, normed chi-square $=2.178\left(\mathrm{x}^{2}=668.626, \mathrm{df}=307, \mathrm{p}\right.$ $=0.00)$, RMSEA $=0.069$ and RMR 0.076 . Furthermore, all $ß$-weights were significant at $\mathrm{p}<$ 0.001 with standardized factor loadings ranging from 0.601 to 0.988 ( $\mathrm{t}$-values of 7.915 to 50.372 ).
The results of the measurement model achieved the acceptable model fit criterion and the model is fit for further analysis such as structural modelling for hypothesis testing.

The construct validity and convergent validity (average variance extracted, AVE) were referred to test the robustness of the model. Table 1 shows the standardized factor loadings for all the items are exceeding the recommended value of 0.5 (Hair et al., 2010). Composite reliability values that depict the degree to which the construct indicators reflect the latent construct are in the range of 0.67 to 0.96 . The results exceeded the recommended value of 0.7 (Hair et al., 2010), 0.6 (Fornell and Larcker, 1981; Tseng et al., 2006). The average variance extracted (AVE) values that reflect the overall amount of variance in the indicators as accounted for by the latent construct are in the range of 0.58 to 0.91 , which exceeded the recommended value of 0.5 (Fornell and Larcker, 1981; Hair, et al., 2010).

In order to further confirm the reliability of the construct, the average variance extracted (AVE) and construct reliability (CR) are calculated based on the formula by Fornell and Larcker (1981). Construct validity testifies how well the results obtained from the use of the measure fit the theories around which the test is designed (Sekaran and Bougie, 2010). Construct validity can be examined through convergent and discriminant validity. Discriminant validity can be tested by comparing the correlations between constructs and the square root of the average variance extracted (AVE) for a given construct.

Following Zait and Bertea (2011), it is necessary to obtain a matrix where the correlation of each construct can be seen. The AVE values were inserted on the diagonal in order to compare it with the other correlation coefficient and the value of AVE.

As shown in Table 2, it can easily be seen that the AVE values are above 0.5 and are above the correlation coefficients for each type of the construct showing satisfactory of discriminant validity (Sridharan et al., 2011).

\subsection{Structural model and mediating effects of satisfaction with complaint handling}

Arbuckle and Wothke (1999) defined structural model as the portion of the model that specifies how the latent variables are related to each other. The goals of the structural model are to specify which latent constructs directly or indirectly influence the values of other latent constructs in the model (Byrne, 2010).

Once all constructs in the measurement model (stage one) were validated and satisfactory fit achieved (Anderson and Gerbing, 1988; Kline, 2005; Hair et al., 2010), a structural model can then be tested and presented as a second and main stage of the analysis. Hence, the purpose of the structural model in this study is to test the underlying hypotheses: 
H1: SATCOM mediates the relationship between consumer complaint behaviour (PCSA) and relationship quality.
H2: SATCOM mediates the relationship between consumer complaint behaviour (PCEA) and relationship quality.

Table 1: The result of construct reliability and average variance extracted

\begin{tabular}{|c|c|c|c|c|c|}
\hline Construct & Items & Standardized Loadings & Cronbach's Alpha $(\alpha)$ & $\mathrm{CR}$ & AVE \\
\hline \multirow{3}{*}{ Public Complaint Soft Action } & CCB1 & 0.60 & 0.72 & 0.71 & 0.59 \\
\hline & CCB2 & 0.87 & & & \\
\hline & CCB3 & 0.80 & & & \\
\hline \multirow{4}{*}{ Public Complaint Extreme Action } & $\mathrm{CCB} 4$ & 0.86 & 0.73 & 0.76 & 0.58 \\
\hline & CCB5 & 0.70 & & & \\
\hline & CCB6 & 0.77 & & & \\
\hline & CCB7 & 0.71 & & & \\
\hline \multirow{4}{*}{ SATCOM } & SATCOM1 & 0.89 & & & \\
\hline & SATCOM2 & 0.92 & & & \\
\hline & SATCOM3 & 0.87 & & & \\
\hline & SATCOM4 & 0.82 & 0.92 & 0.91 & 0.77 \\
\hline \multirow{2}{*}{ Trust in Partner's Honesty } & RQ2 & 0.97 & 0.89 & 0.86 & 0.82 \\
\hline & RQ3 & 0.84 & & & \\
\hline \multirow{2}{*}{ Trust in Partner's Benevolence } & RQ5 & 0.92 & 0.87 & 0.87 & 0.80 \\
\hline & RQ6 & 0.87 & & & \\
\hline \multirow{3}{*}{ Affective Commitment } & RQ7 & 0.72 & 0.86 & 0.82 & 0.68 \\
\hline & RQ8 & 0.91 & & & \\
\hline & RQ9 & 0.84 & & & \\
\hline \multirow{3}{*}{ Satisfaction } & RQ10 & 0.93 & 0.97 & 0.97 & 0.93 \\
\hline & RQ11 & 0.99 & & & \\
\hline & RQ12 & 0.94 & & & \\
\hline
\end{tabular}

Table 2: Discriminant validity of constructs for complainers

\begin{tabular}{lccccccc}
\hline & 1 & 2 & 5 & 6 & 7 & 8 & 9 \\
1. PCSA & $\mathbf{0 . 5 8 6}$ & & & & & & \\
2. PCEA & 0.167 & $\mathbf{0 . 5 8 2}$ & & & & & \\
3. SATCOM & 0.234 & -0.033 & $\mathbf{0 . 7 6 7}$ & & & & \\
4. TiPH & 0.119 & 0.014 & 0.650 & $\mathbf{0 . 8 2 3}$ & & \\
5. TiPB & 0.170 & 0.050 & 0.586 & 0.792 & $\mathbf{0 . 8 0 2}$ & & \\
6. AfCM & -0.004 & 0.088 & 0.515 & 0.553 & 0.337 & $\mathbf{0 . 6 8 4}$ & $\mathbf{0 . 9 1 0}$ \\
7. SAT & 0.115 & -0.006 & 0.683 & 0.688 & 0.598 & 0.552 & \\
\hline
\end{tabular}

PCSA = Public Complaint Soft Action; PCEA = Public Complaint Extreme Action; SATCOM = Satisfaction with Complaint Handling; TiPH = Trust in Partner; Honesty; TiPB = Trust in Partner's Benevolence; AfCM = Affective Commitment; SAT = Satisfaction

In evaluating the structural model, the goodness-of-fit indices are examined to assess if the hypothesized structural model fits the data. Respecification needs to be performed if the goodnessof-fit does not meet the acceptable statistical fit. Besides, the model must indicate a theoretically meaningful representation of the observed data (Anderson and Gerbing, 1988; Hair et al., 2010, Tabachnick and Fidell, 2007; Kline, 2005). The coefficient parameter estimates were examined along with the overall model fit indices to test hypotheses $\mathrm{H} 1$ to $\mathrm{H} 5$ once the underlying structural equation modelling was met. According to Tabachnick and Fidell (2007), parameter estimates are fundamental to SEM analysis because they are used to generate the estimated population covariance matrix for the model. Coefficient values are obtained by dividing the variance estimate by its Standard Error (S.E) that is, when the Critical Ratio (C.R.) (called z-value) is greater than 1.96 for a regression weight (or standardized estimates); the parameter is statistically significant at the .05 levels.

The goodness-of-fit indices indicate that the hypothesized model as shown in Fig. 1, fits the data adequately with all fit indices showing reasonable values of $\mathrm{x}^{2}=695.922, \mathrm{df}=310, \mathrm{p}=0.000, \mathrm{CFI}=$ $0.932, \mathrm{TLI}=0.923, \mathrm{NFI}=0.884, \mathrm{RMSEA}=0.071$ and PNFI $=0.781$. Table 3 presents the results of direct effect, indirect effect, total effect and the degree of mediation of the hypothesized paths. The results show that hypotheses $\mathrm{H}_{1}$ is supported, however hypothesis $\mathrm{H}_{2}$ is not supported. This indicates SATCOM is a significantly full mediator of the relationship between PCSA and relationship quality $(\beta=0.246, p=0.000$, BC 95\% CI [0.047, 0.282]), but not a mediator of the relationship between PCEA and relationship quality $(\beta=-0.096, p=0.169, \mathrm{BC} 95 \% \mathrm{CI}$ $[-0.174,0.031])$. Table 4 displays further results of the mediation analysis.

Two hypotheses were posited $\left(\mathrm{H}_{1}\right.$ and $\left.\mathrm{H}_{2}\right)$ to identify the effects of SATCOM on the relationship between CCB and relationship quality. Consistent with the previous study (Orsingher et al., 2010); the results were found to be mixed where SATCOM was a full mediator on the relationship between CCB (PCSA) and relationship quality. It was not a mediator on the relationship between CCB (PCEA) and relationship quality. This finding implies that 
customers who are angry or dissatisfied may opt to this action, and they officially write to the service provider or any other relevant authorities. The performance of the complaint resolution by the service provider will give impact to the consumer as well to the service provider because customer dissatisfaction can be recovered faster through high level of SATCOM. Conversely, the low level of SATCOM may result in more serious effect (Pei and Qiu, 2006) such as low return intention (Ro, 2014) and word of mouth (Piaralal et al., 2014).

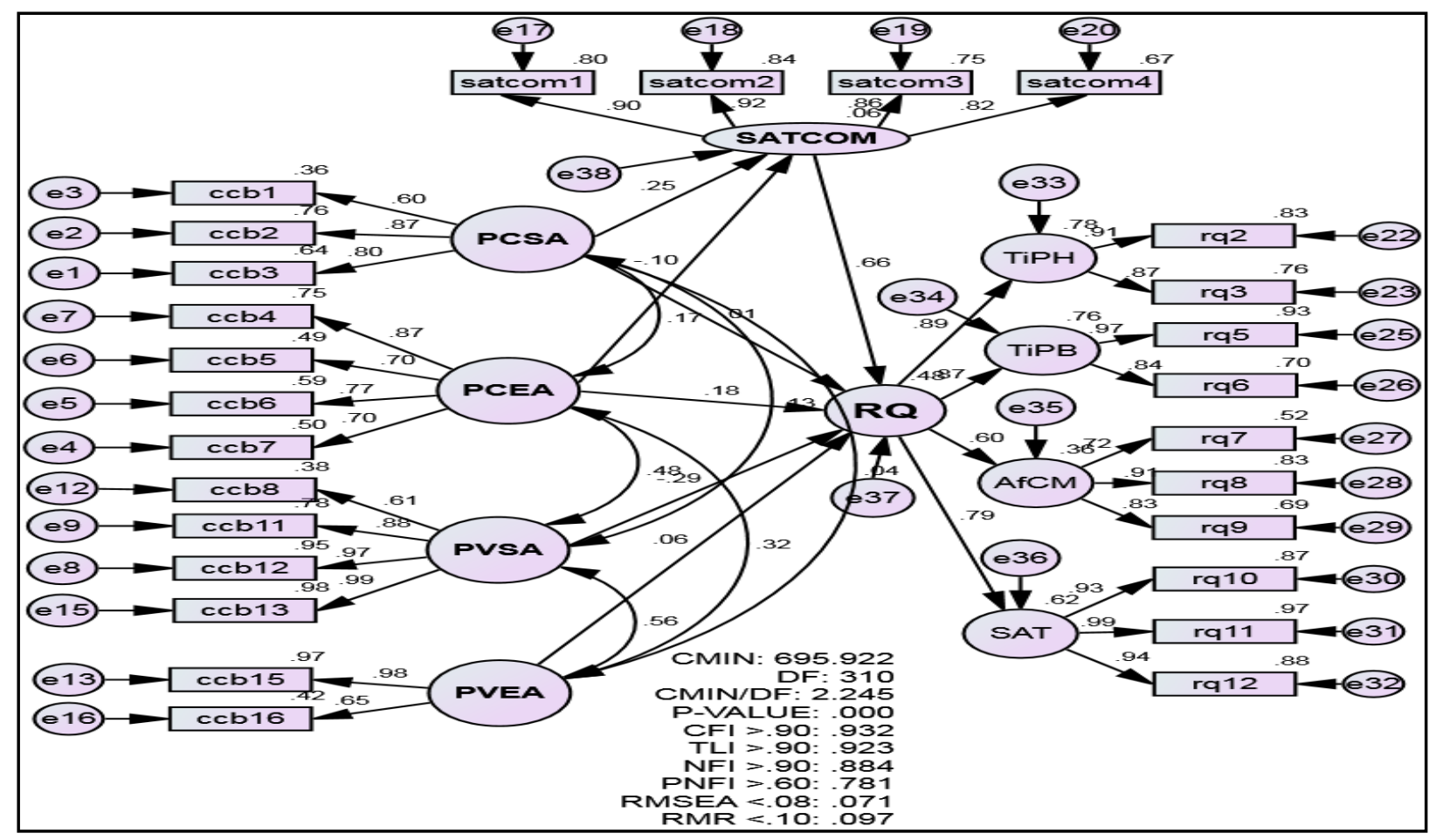

Fig. 1: The hypothesized model

Table 3: The result of mediation test using bootstrapping method

\begin{tabular}{ccccccccc}
\hline Predictor & $\rightarrow$ & Mediator & $\rightarrow$ & Criterion & Direct Effect & Indirect Effect & Total Effect & Degree of Mediation \\
\hline PCSA & $\rightarrow$ & SATCOM & $\rightarrow$ & RQ & 0.968 & 0.002 & 0.065 & Full \\
PCEA & $\rightarrow$ & SATCOM & $\rightarrow$ & RQ & 0.012 & 0.177 & 0.198 & No \\
\hline
\end{tabular}

Table 4: Further result of mediation test using bootstrapping method

\begin{tabular}{|c|c|c|c|c|c|}
\hline \multirow[b]{2}{*}{ Path } & \multirow[b]{2}{*}{$\begin{array}{c}\text { Standardized } \\
\text { Indirect Estimates }\end{array}$} & \multirow[b]{2}{*}{$\begin{array}{l}\text { Standard } \\
\text { Error }\end{array}$} & \multicolumn{3}{|c|}{ Bias Corrected 95\% Confidence Interval } \\
\hline & & & $\begin{array}{l}\text { Lower } \\
\text { Bound }\end{array}$ & $\begin{array}{l}\text { Upper } \\
\text { Bound }\end{array}$ & $\mathrm{p}$ \\
\hline $\mathrm{PCSA} \rightarrow \mathrm{RQ}$ & 0.246 & 0.076 & 0.047 & 0.282 & 0.000 \\
\hline $\mathrm{PCEA} \rightarrow \mathrm{RQ}$ & -0.096 & 0.080 & -0.174 & 0.031 & 0.169 \\
\hline
\end{tabular}

\section{Conclusion}

The current study purify and validate the complaint behaviour, satisfaction with complaint handling and relationship quality scale and provide a psychometrically sound scale for future use. After a 2-stage process of purification and cross-validation, the final model show 3 items were removed from the original CCB, 1 item from SATCOM and 5 items from relationship quality. The results showed that the 28item scale is more parsimonious and more stable for this model. The confirmatory factor analysis has confirmed that the four subscales four relationship quality are acceptably unidimensional, which is important in scale development and purification processes. The results confirm that SATCOM is a mediator which mediates the relationship between CCB (PCSA) and relationship quality but does not mediate the relationship between CCB (PCEA) and relationship quality. Thus, parties who are involved in providing mobile phone services to consumers should take the finding that reckons satisfaction with complaint handling as the mediator seriously. This is to ensure the relationship between the consumers and the service providers is perpetuated for mutual benefit and to improve the level of relationship quality.

\section{References}

Alicke MD, Braun JC, Glor JE, Klotz ML, Magee J, Sederhoim H, and Siegel R (1992). Complaining behaviour in social interaction. Personality and Social Psychology Bulletin, 18(3): 286-295.

Ambrose M, Hess RH, and Ganesan S (2007). The relationship between justice and attitudes: An examination of justice effects on event and system-related attitudes. Organizational Behaviour and Human Decision Processes, 103(1): 21-36.

Anderson JC and Gerbing DW (1988). Structural equation modeling in practice: A review and recommended two-step approach. Psychological Bulletin, 103(3): 411-423. 
Andreassen TW (1999). What drives customer loyalty with complaint resolution?. Journal of Service Research, 1(4): 324 332.

Arbuckle JL and Wothke W (1999). AMOS 4.0 User's guide. SPSS, Chicago, USA.

Athanasopoulou P (2006). Determining relationship quality in the development of business-to-business financial services. Journal of Business to Business Marketing, 13(1): 87-120.

Bagozzi RP and Yi Y (1988). On the evaluation of structural equation models. Academy of Marketing Science, 16(1): 76-94.

Bearden WO and Oliver RL (1985). The role of public and private complaining in satisfaction with problem resolution. Journal of Consumer Affairs, 19(2): 222-240.

Bennett R and Barkensjo A (2005). Relationship quality, relationship marketing, and client perceptions of the levels of service quality of charitable organisations. International Journal of Service Industry Management, 16(1): 81-106.

Blodgett JG and Granbois DH (1992). Toward an integrated conceptual model of consumer complaining behaviour. Journal of Consumer Satisfaction, Dissatisfaction and Complaining Behaviour, 5(1): 93-103.

Boles JS, Johnson JT, and Barksdale HC (2000). How sales person build quality relationships: A replication and extension. Journal of Business Research, 48(1): 75-81.

Byrne BM (2010). Structural equation modelling with AMOS: Basic concept application and programming. Lawrence Erlbaum Associates, London, England.

Carriere J and Bourque C (2009). The effects of organizational communication on job satisfaction and organizational commitment in a land ambulance service and the mediating role of communication satisfaction. Career Development International, 14(1): 29-49.

Caruana A (2002). Service loyalty: The effects of service quality and the mediating role of customer satisfaction. European Journal of Marketing, 36(7): 811-828.

Chiu RK and Francesco AM (2003). Dispositional traits and turnover intention: Examining the mediating role of job satisfaction and affective commitment. International Journal of Manpower, 24(3): 284-298.

Crie D (2003). Consumers' complaint behavior taxonomy, typology and determinants: Towards a unified ontology. Journal of Database Marketing and Customer Strategy Management, 11(1): 60-79.

Cronbach LJ (1951). Coefficient alpha and the internal structure of tests. Psychometrika, 16(3): 297-334.

Crosby LA, Kenneth RE, and Cowles D (1990). Relationship quality in services selling: An Interpersonal Influence perspective. Journal of Marketing, 54(3): 68-81.

Day RL and Landon EL (1977). Toward a theory of consumer complaining behavior. Consumer and Industrial Buying Behavior, 95: 425-437.

De Ruyter K, Moorman L, and Lemmink J (2001). Antecedents of commitment and trust in customer-supplier relationships in high technology markets. Industrial Marketing Management, $30(3): 271-286$.

De Wulf K, Oderkerken-Schr"oder G, and Iacobucci D (2001). Investment in consumer relationships: A cross-country and cross-industry exploration. Journal of Marketing, 65(4): 33 50 .

Dunn SC, Seaker RF, and Waller MA (1994). Latent variables in business logistics research: Scale development and validation. Journal of Business Logistics, 15(2): 145-172.

Etzel MJ and Silverman BI (1981). A managerial perspective on directions for retail customer dissatisfaction research. Journal of Retailing, 50(3): 124-136.
Fornell C and Larcker DF (1981). Structural equation models with unobservable variables and measurement error: Algebra and statistics. Journal of Marketing Research, 18(3): 382-388.

Gelbrich K and Roschk H (2011). A meta-analysis of organizational complaint handling and customer responses. Journal of Service Research, 14(1): 24-43.

Goodman LE and Dion PA (2001). The determinants of commitment in the distributor-manufacturer relationship. Industrial Marketing Management, 30(3): 287-300.

Grönroos C (1988). Service quality: The six criteria of good perceived quality. Review of Business, 9(3): 10-13.

Hair Jr JF, Black WC, Babin BJ, and Anderson RE (2010). Multivariate data analysis. Prentice Hall, New Jersey, USA.

Harris KE, Grewal D, Mohr LA, and Bernhardt KL (2006). Consumer responses to service recovery strategies: The moderating role of online versus offline environment. Journal of Business Research, 59(4): 425-431.

Hennig-Thurau T and Klee A (1997). The impact of customer satisfaction and relationship quality on customer retention: A critical reassessment and model development. Psychology and Marketing, 14(8): 737-764.

Heung VC and Lam T (2003). Customer complaint behavior towards hotel restaurant services. International Journal of Contemporary Hospitality Management, 15(5): 283-289.

Ho R (2006). Handbook of univariate and multivariate data analysis and interpretation with SPSS. CRC Press, New York, USA.

Homburg C and Furst A (2005). How organizational complaint handling drives customer loyalty: An analysis of the mechanistic and the organic approach. Journal of Marketing, 69(3): 95-114.

Hsieh YC and Hiang ST (2004). A study of the impacts of service quality on relationship quality in search-experience-credence services. Total Quality Management and Business Excellence, 15(1): 43-58.

Hunt DH and Hunt KH (1990). Customer grudge holding: Further conceptualization and analysis. Journal of Consumer Satisfaction, Dissatisfaction and Complaining Behavior, 3: 117-122.

Kau AK and Loh EWY (2006). The effects of service recovery on consumer satisfaction: A comparison between complainers and non-complainers. Journal of Services Marketing, 20(2): 101-111.

Kim C, Kim S, Im S, and Shin C (2003). The effect of attitude and perception on consumer complaint intentions. Journal of Consumer Marketing, 20(4): 352-371.

Kim WG, Lee YK, and Yoo YJ (2006). Predictors of relationship quality and relationship outcomes in luxury restaurants. Journal of Hospitality and Tourism Research, 30(2): 143-169.

Kline RB (2005). Principles and practice of structural equation modeling. The Guilford Press, New York, USA.

Lagace RR, Dahlstrom R, and Gassenheimer JB (1991). The relevance of ethical salesperson behaviour on relationship quality in the pharmaceutical industry. Sales Management, 11(4): 39-47.

Leuthesser L (1997). Supplier relational behaviour: an empirical assessment. Industrial Marketing Management, 26(3): 245 254.

Lin CP and Ding CG (2005). Opening the black box: Assessing the mediating mechanism of elationship quality and the modrating effects of prior experience in ISP service. International Journal of Service Industry Management, 16(1): 55-80.

Liu RR and McClure P (2001). Recognizing cross-cultural differences in consumer complaint behavior and intentions: 
An empirical examination. Journal of Consumer Marketing, 18(1): 54-75.

Lok P and Crawford J (2001). Antecedents of organizational commitment and the mediating role of job satisfaction. Journal of Managerial Psychology, 16(8): 594-613.

Malaysian Communication and Multimedia Commission (MCMC) (2015). Hand phone users survey, 2014. Putrajaya, Malaysia.

Maxham JG and Netemeyer RG (2002). Modeling customer perceptions of complaint handling over time: The effects of perceived justice on satisfaction and intent. Journal of Retailing, 78 (4): 239-252.

McCollough MA, Berry LL, and Yadav MS (2000). An empirical investigation of customer satisfaction after service failure and recovery. Journal of Service Research, 3(2): 121-137.

Menon A, Bharadwaj SG, and Howell RD (1996). The quality and effectiveness of marketing strategy: Effect of functional and dysfunctional conflict in intra organizational relationships. Journal of Academy of Marketing Science, 24(4): 299-313.

Mount M, Ilies R, and Johnson E (2006). Relationship of personality traits and counterproductive work behaviours: The mediating effects of job satisfaction. Personnel Psychology, 59(3): 591-622.

National Consumer Complaints Centre (NCCC) (2015). Annual report 2014. NCCC, Selangor, Malaysia.

Ndubisi NO (2007). Relationship marketing and customer loyalty. Marketing Intelligence and Planning, 25(1): 98-106.

Ndubisi NO and Ling TY (2006). Complaint behavior of Malaysian consumers. Management Research News, 29(1): 65-76.

Oliver RL (1997). Satisfaction: A behavioural perspective on the consumer. Irwin McGraw-Hill, Boston, USA.

Orsingher C, Valentini S, and de Angelis M (2010). A meta-analysis of satisfaction with complaint handling in services. Journal of the Academic Marketing Science, 38(2): 169-186.

Pei WD and Qiu HY (2006). Research of customer complaints and service recovery effects. In the International Conference on Management Science and Engineering (ICMSE '06). IEEE: 958962. https://doi.org/10.1109/ICMSE.2006.314008

Piaralal NK, Piaralal SK, and Bhatti MA (2014). Antecedent and outcomes of satisfaction with service recovery: A study among mobile phone users in central region of Malaysia. Asian Social Science, 10(12): 210-230.

Rahman MKBA, Haron SA, Paim LH, Othman M, Osman S, and Othman AK (2015). Construct validation of consumer complaint behavioral scale in the Malaysian mobile phone services industry. Asian Social Science, 11(24): 6-17.

Richins ML (1983). Negative word-of-mouth by dissatisfied consumers: A pilot study. Journal of Marketing, 47(1): 68-78.

Ro H (2014). Complaint, patience, and neglect: Responses to a dissatisfying service experience. Service Business, 8(2): 197216.
Roberts K, Varki S and Brodie R (2003). Measuring the quality of relationships in consumer services: An empirical study. European Journal of Marketing, 37(1/2): 169-196.

Roloff ME and Miller GR (1987). Interpersonal processes: New directions in communication research. SAGE, California, USA.

Sanzo MJ, Santos ML, Vázquez R, and Álvarez LI (2003). The effect of market orientation on buyer-seller relationship satisfaction. Industrial Marketing Management, 32(4): 327345.

Sekaran U and Bougie R (2010). Research methods for business: A skill building approach. Wiley, West Sussex, UK.

Shapiro T and Nieman-Gonder J (2006). Effect of communication mode in justice-based service recovery. Managing Service Quality, 16(2): 124-144.

Singh J (1988). Consumer complaint intentions and behavior: Definitional and taxonomical issues. Journal of Marketing, 52(1): 93-107.

Smith JB (1998). Buyer-seller relationships: Similarity, relationship management, and quality. Psychology and Marketing, 15(1): 3-21.

Sridharan B, Deng H, Kirk J, and Corbitt B (2011). Structural equation modeling for evaluating the user perceptions of elearning effectiveness in higher education. In the $18^{\text {th }}$ European Conference on Information Systems (ECIS '10), Pretoria, South Africa: 1-13.

Stauss B (2002). The dimensions of complaint satisfaction: Process and outcome complaint satisfaction versus cold fact and warm act complaint satisfaction. Managing Service Quality, 12(3): 173-183.

Tabachnick BG and Fidell LS (2007). Using multivariate statistics. Pearson Education, Boston, USA.

Tax SS, Brown SW, and Chandrashekaran M (1998). Customer evaluations of service complaint experiences: Implications for relationship marketing. Journal of Marketing, 62(2): 60-76.

Tronvoll B (2011). Negative emotions and their effects on customer complaint behavior. Journal of Service Management, 22(1): 111-134.

Tseng WT, Dörnyei Z, and Schmitt N (2006). A new approach to assessing strategic learning: The case of self-regulation in vocabulary acquisition. Applied Linguistics, 27(1): 78-102.

Varela-Neira C, Vázquez-Casielles R, and Iglesias V (2010). Explaining customer satisfaction with complaint handling. International Journal of Bank Marketing, 28(2): 88-112.

Weun S, Beatty SE, and Jones MA (2004). The impact of service failure severity on service recovery evaluations and postrecovery relationships. Journal of Services Marketing, 18(2): 133-146.

Zait PA and Bertea PE (2011). Methods for testing discriminant validity. Management and Marketing Journal, 9(2): 217-224. 